\title{
Impact of COVID-19 on Public Transportation and Road Safety in Bangladesh
}

\author{
Md. Ebrahim Shaik ${ }^{1}$ (D) Quazi Sazzad Hossain ${ }^{1}$ - G. M. Forhad Faisal Rony ${ }^{1}$
}

Received: 26 August 2021 / Accepted: 3 September 2021 / Published online: 9 September 2021

(c) The Author(s), under exclusive licence to Springer Nature Singapore Pte Ltd 2021

\begin{abstract}
Due to the spread of COVID-19, global measures such as lockdown and limits on public transit, entertainment, the closure of all educational institutions, and religious practices have been imposed in early 2020. During and after the COVID-19 disease outbreak, the first target ought to be safer road travel and zero fatalities. This paper general overviews the effects of the government's COVID-19 control measures on Bangladesh's transportation system and road safety during the period March 2020-2021. Secondary data sources, newspaper articles, WHO, Worldometer, Institute of Epidemiology, Disease Control and Research (IEDCR) websites, and relevant research papers were used to compile this article. The various restriction policies would have a negative impact on the transportation sector's finances, exacerbating the economic crisis that public transportation and airline operators in Bangladesh are experiencing. This study found that restricting mobility reduces road traffic deaths and injuries by a small amount, but that accidents continue to occur during the lockdown period in Bangladesh.
\end{abstract}

Keywords COVID-19 $\cdot$ Public transport $\cdot$ Road safety $\cdot$ Accident $\cdot$ Lockdown

\section{Introduction}

In December 2019, patients in Wuhan, China, were first diagnosed with COVID-19, a novel coronavirus [1] and the World Health Organization (WHO) announced it as a worldwide pandemic at the beginning of March 2020 and urged countries and public health authorities to respond and limit the number of new cases and deaths predicted [2,3]. COVID-19 has had a huge impact on the world's life condition in more than a year, and it continues to do so. To limit the occurrence of virus and probable casualties, the majority of governments around the world implemented lockdowns.

This article is part of the topical collection "Advances in Computational Approaches for Artificial Intelligence, Image Processing, IoT and Cloud Applications" guest edited by Bhanu Prakash K. N. and M. Shivakumar.

Md. Ebrahim Shaik

ebrahimkuet82@gmail.com

Quazi Sazzad Hossain

sazzad@ce.kuet.ac.bd

G. M. Forhad Faisal Rony

gmfarad07@gmail.com

1 Department of Civil Engineering, Khulna University of Engineering \& Technology, Khulna 9203, Bangladesh
Because of the relatively limited available space, public transit stations and automobiles are considered the highest risk area for the spread of COVID-19 [4]. Since road traffic and air travel were two of the key dimensions for the spread of the COVID-19, one of the limitations imposed was a restriction on personal mobility [5].

Since the entirety of the world's population is on "lockdown," road traffic numbers and movement behaviors on highways have declined [6]. According to study of different research, urban traffic has decreased everywhere in the world, but still not equally for all modes; public transport system has taken the biggest hit [7]. A significant outcome of the COVID-19 prevention strategies was a decrease in traffic collisions on both urban and interurban highways, which resulted in a significant decline in traffic-related accidents and fatalities [8]. Well before the ongoing health crisis, traffic fatalities identified a worldwide pandemic. Every year, around 1.35 million people die on the road all over the globe, with another 20-50 million injured, for a death rate of 27.5 deaths per 100,000 people [9]. Road accidents, which result in property damages and economic losses, are one of the terrible impacts of mobility [10]. Following the COVID-19 epidemic, mobility controls were implemented, resulting in a significant decrease in road traffic accident [8]. 
Bangladesh, a high population density-developing nation in South Asia with a population of 161.3 million, is threatening a crisis as a result of this virus's rapid spread [11]. Bangladesh's first national lockdown which began in March 2020 and was prolonged several periods before being ended in May due to economic difficulties. All public transportation in the country has been shut down, with the exception of trucks, covered buses, and vehicles transporting medicine, gasoline, and perishable goods [12]. When people were only permitted to leave the house for designated important purposes, it became clear that vehicular traffic flows and congestion were drastically reduced. There were expectations that with the decrease of vehicular traffic, there would be fewer accidents, fatalities, and injuries on the highways. Road traffic is reduced, which means there are less chances for road users to be involved in collisions [13]. In a new decision, the government has agreed to begin limited public transportation, road, rail, and waterways on May 31, 2020 [14].

COVID-19 would intensify the effects of the government's multiple challenges, resulting in a multifactorial problems. The main objective of this research was to analyze the influence of the COVID-19 shutdown on road traffic accidents and the effects on different modes of transportation in Bangladesh. This study will add to the increasing body of knowledge about the COVID-19 pandemic's multiple impacts on Bangladesh's transportation system and traffic safety. This article was developed using secondary data sources, data from media reports, WHO, Worldometer, Institute of Epidemiology Disease Control and Research (IEDCR) websites, and related research articles.

After a brief introduction to the issue, the paper goes on to a short discussion of COVID-19 Epidemiology and Synopsis in Bangladesh. Then, the situation of fatal crashes and different modes of public transport due to effect COVID-19 was analyzed. The situation of traffic fatalities and various modes of public transportation as a result of the COVID-19 impact was then examined. Finally, a discussion and conclusions are drawn.

\section{COVID-19 Epidemiology and Synopsis in Bangladesh}

In Bangladesh, Institute of Epidemiology, Disease Control and Research (IEDCR), announced the first three known cases on March 8, 2020. On March 18, 2020, Bangladesh announced its first confirmed COVID-19 death, 10 days after the first confirmed case. On March 22, 2020 to secure the population, the government imposed a 10-day "lockdown" across the country from March 26 to April 4 [15], which was later extended to May 30, 2020 [14]. Since it is difficult to restrict people's sources of income indefinitely as a developing nation, the government has agreed not to prolong the current shutdown beyond May 30 [14]. At the beginning of the infection in the country, the rate of patient identification was low. The infection began to spread in the middle of May, and the patient recognition rate was over $20 \%$ from the last week of May to the third week of August. Bangladesh has tested a relatively small number of people for COVID-19 in comparison to its population. In addition, the situation has deteriorated due to a shortage of PCR devices, adequate biosafety laboratories, inadequate testing kits, and incompetent health staff. The rate of new patient recognition started to decline from that point on [16].

Figure 1 illustrates the monthlies total number of people infected and deaths, as well as the total number of people tested and recovered, from March 2020 to March 2021. The total number of infections peaked in June and steadily declined over the summer. In early November, 2020 after a couple of months of decreasing infection rates, the upward trend in new patient and detection rates began. The infection started to decline again in December 2020. Due to COVID19 cases totaled 6, 11,295 as of March 31, 2021, with 9046 deaths in this country. However, the infection has been on the increase again since March 2021 [17].

\section{Fatal Crashes in Bangladesh}

In 1 month of the ongoing lockdown, which began on March 26, 2020 and was imposed to control the spread of COVID-19 in the country, 211 persons were dead and 227 others were injured in 201 road incidents throughout the country [18]. At least 150 persons were dead in the first 15 days of April 2020, according to Bangladesh Jatri Kalyan Samity, which collects data on road accidents based on media reports, bringing the average to ten fatalities a day [19]. This implies that even though many automobiles have been off the highway since March 26, 2020 due to a government-mandated public holiday, there has

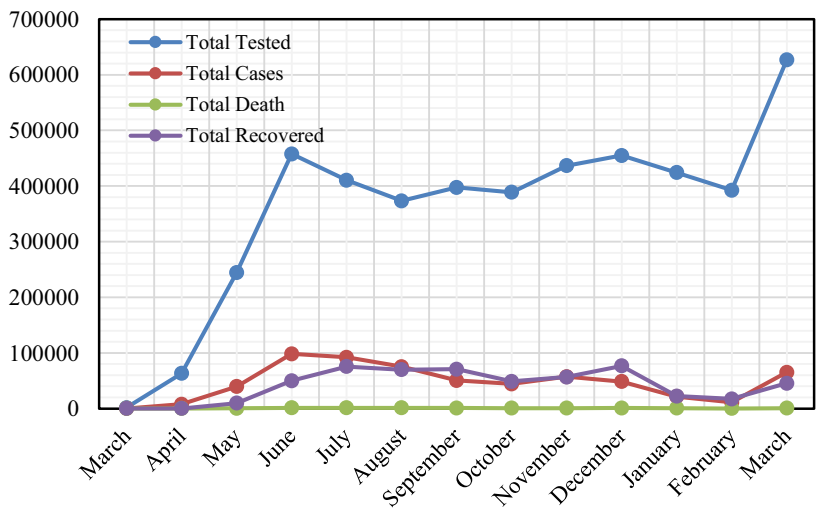

Fig. 1 Monthlies statistics of total cases, deaths, tested and recovered from March 2020 to March 2021 
been little effect on fatal crashes. Besides that, motorcycles were engaged in the majority of the crashes this month, while trucks transporting inter-district supplies were also included in a few. Even though public transportation was suspended for more than 2 months to control the COVID19 crisis, 6686 people were killed and 8600 were injured in 4891 road traffic accidents in Bangladesh in 2020 [20, 21]. In the meantime, 318 persons were dead and 79 others were wounded in 323 train crashes. In 183 collisions on rivers, 313 persons were dead, 342 were injured, and 371 mysteriously disappeared. This implies that 18 people have lost their lives in traffic crashes every day on average throughout the country. While the number of traffic accidents on regional highways raised by $6.78 \%$ compared to 2019 , they declined by $3.45 \%$ on national highways, $0.16 \%$ at rail crossings, and $2.19 \%$ on feeder roads, according to the Bangladesh Passengers Welfare Association's (BPWA) annual report. In comparison to 2019 , there were $21 \%$ fewer fatalities and $18 \%$ fewer deaths in 2020 , which can be due to the COVID-19 pandemic and the traffic restrictions enforced as a result [20]. Even on lockdown days, careless driving, substandard roads, badly managed cars, incompetent drivers violating traffic laws, and a lack of oversight the department of traffic are among the causes of injuries and death.

\section{Impacts on Transport Systems}

COVID-19 has had a significant impact on trade road transport, including traveler and goods, as a result of transportation constraints imposed to combat the epidemic and the broader financial crisis [22]. The epidemic of COVID19 has already forced governments and agencies all over the world to enforce unprecedented transportation and mobility controls [23].

\section{Road Transport}

During the 67-day lockdown enforced to combat the risk of coronavirus, all public transportation activities have been stopped since March 28, 2020. On June 1, 2020 the lockdown was eased to transition to a zonal lockdown policy, but that policy has yet to be enforced. As per the bus owners group, only $25 \%$ of buses are running on long routes and $50 \%$ in Dhaka compared to before the pandemic. Only in an emergency should people drive long distances. To preserve social distance, buses are only permitted to hold $50 \%$ of their number of passengers after the commencement of public transportation. While governments permitted a $60 \%$ increase in fares, passengers say that far too many vehicles have increased fares about $80-90 \%$. When public transportation was reinstated, approximately $98 \%$ of the tickets were sold, but only $14-15 \%$ of the tickets were sold recently [24]. Owners and staff in the transportation industry claimed that they struggled during the shutdown, but now that it has ended, they are unable to meet their basic needs [25].

\section{Water Transport}

Thousands of Bangladeshis, particularly in the country's southern parts, love to travel by ship and commuter boats on a regular basis [12]. Launch and steamer facilities on 34 river paths across the country will restart after more than 2 months, according to the Bangladesh Inland Water Transport Authority (BIWTA) [26]. Following the resumption of public transportation on June 1, launch owners have requested fare increases, claiming that they have been losing money leading to a shortage of travelers. The launch's owners have stated that a $29-36 \%$ increase in fares is needed by the end of the month (June), or the company will be forced to shut down [24]. Launches would be difficult to run as the volume of passengers on board continues to decline.

\section{Air Transport}

To avoid the spread of the virus, governments all over the world have put restrictions on air transport, with the majority of countries banning foreign, domestic, commercial, and passenger flights entirely. Bangladesh prohibited passenger air traffic with all countries except China in midMarch, 2020 sinking the industry into steep losses [27]. The government restricted all flights from Europe excluding the United Kingdom on March 15, 2020, furthermore, flights from Europe were still permitted to arrive at an airport [28]. The army was assigned on March 19 to run two quarantine facilities, one at Ashkona Hajj Camp near Shahjalal International Airport and the other at Rajuk Apartment Project near Uttara Sector-18 in Diabari [29]. According to an estimate by the International Air Transport Association (IATA), the epidemic might decrease passenger numbers in Bangladesh and wipe \$190 million, off airline carriers' profits this year [27]. Since airline companies in Bangladesh have limited capital reserves and less economic ability to ride out the storm, they will be hit harder in the imminent wake of the incident.

\section{Rail Transport}

To limit the occurrence of coronavirus in Bangladesh, governments placed restrictions on the movement of all regional, postal, and commuter trains on March 25, 2020 [30-32]. The Bangladesh Railway (BR) reopened in early 
June with 18 pairs of trains and 50\% of seats sold out [24]. Following the resumption of public transportation on June 1 , rail availability will be cut in half in order to comply with the maintaining health safety guidelines for the next 16 days [33]. Train services have indeed been largely halted for over a month, putting Bangladesh Railway at risk of losing money. The Eid period, when Bangladesh Railway makes the most money, which was really a challenge this year due to the epidemic in 2020 [34]. Therefore, after the halt of all train services throughout the country due to the COVID-19 epidemic, Bangladesh Railway was losing Tk 4-5 crore in revenue every day [35].

\section{Discussions}

Working for a resilient recovery in a world environment changed by the pandemic necessitates taking advantage of new opportunities to create a more prosperous and sustainable future. Improving traffic safety will be critical to achieving this goal, as it will aid in the development of epidemic health care systems as well as safer travel [36]. Companies in public vehicle in Bangladesh will face important questions about their potential profitability as passenger numbers declines. After the resumption, public transportation owners and employees have reported massive losses, because few passengers choose to travel by public transportation in the lockdown situation. Since the resumption of public transport, private and public vehicle use dropped because many people were allowed to work from home, and office work may become the new standard for a much greater proportion of employees in the future [4]. In the immediate future, the government must strive to strengthen its ICT Cloud services while also motivating citizens to upgrade their overall digital literacy and applicability.

Daily outbreaks in Bangladesh started to drop in midDecember, 2020 touching a lowest of 305 on February 6, but infection rates began to increase in mid-March 2021 [37]. Due to an increase in new infections and deaths from the virus, Bangladesh's government again imposed a 9-day lockdown on April 5, 2021, closing down offices, shopping centers, and public transportation across the country [38]. To avoid and manage the dissemination of COVID-19, the government implemented a number of measures. Most citizens in Bangladesh who live on unstable incomes faced the daunting option of contracting a pandemic or going hungry due to a lack of access to work and income during these lockdown.

When lockdowns were implemented in Bangladesh, mobility decreased dramatically. Even so, in the weeks following the start of the restriction, the limitations on movement gradually eased, enabling wider groups of people and events to move about. Unfortunately, this resulted in continue in road collisions, as well as the fatalities and injuries that resulted from them. These unexpected movement restrictions have also resulted in some positive changes in the environment. Traffic restrictions imposed in response to COVID-19 have resulted in fresh air, which had a significant impact on human health. COVID-19 may be the real motivation for a change in mobility strategies, especially in urban areas, toward more ecologically sound and public solutions.

To avoid a rise in traffic accident rates, effective traffic safety measures should be performed immediately. Alternatives to public transportation should also be explored by governments. It is highly expected that assigning cycle lanes to bicycles and pedestrians while reducing the free space for cars would inspire people to travel their bicycles or walk instead of driving or travel by car [39]. According to a research survey, during the new normal condition, 56\% and $45 \%$ of respondents planned to increase their walking and bike travel, respectively. In addition, from the other side, $19 \%$ of those polled were predicted to do the exact opposite [40]. Furthermore, pedestrian and cycling infrastructure, as well as information and communication technology (ICT), must be modernized. From these discussions, the government needs to make improving cleanliness measures in public transportation and rickshaws a high priority [41].

\section{Conclusions}

The impact of the control measures of the government's COVID-19 control measures on Bangladesh's public transportation and road safety are described in this article. The government had halted all public transportation operations during the 67-day lockout imposed to combat the risk of coronavirus. Furthermore, public transportation vehicles must only run at $50 \%$ of their full capacity. These strategies will be detrimental to the transportation sector's finances, enhancing the economic meltdown faced by public transportation and airline operators in Bangladesh. Since more private cars are being driven due to a potential inability to use public transportation, the number of traffic incidents has continued to rise in comparison to the same timeframe in previous years. However, as the restrictions on travel were steadily lifted during the lockdown period, traffic accidents and the deaths and injuries that resulted continued. Our analysis show that a restriction in mobility leads to a marginal reduction in road traffic fatalities and incidents. The present crisis must serve as a catalyst both for governments and people to engage in innovative and constructive activities to ensure that all Bangladeshis have access to safer roads.

Due to the limited data and information available, more advanced methods were not used in this study, but it will be included in future research. If sufficiently high-quality 
data are available, a more detailed image of the impact of COVID-19 and lockdown on road safety and transportation systems could be developed, but it is one that could be explored in future studies.

\section{Declarations}

Conflict of interest On behalf of all the authors, the corresponding author states that there is no conflict of interest.

\section{References}

1. Zhu N, Zhang D, Wang W, Li X, Yang B, Song J, Zhao X, Huang B, Shi W, Lu R, Niu P, Zhan F, Ma X, Wang D, Xu W, Wu G, Gau GF, Tan W. A Novel Coronavirus from patients with pneumonia in China, 2019. N Engl J Med. 2020;382:7323-733.

2. World Health Organization, W., 2020. WHO Director-General's opening remarks at the media briefing on COVID-19-11 March 2020. WHO Dir, Gen, speeches.

3. Arellana J, Márquez L, Cantillo V. COVID-19 Outbreak in Colombia: an analysis of its impacts on transport systems. J Adv Transport. 2020;8867316

4. Musselwhit C, Avineri E, Susilo Y. Editorial JTH 16-the Coronavirus Disease COVID-19 and implications for transport and health. J Transport Health. 2020;16:100853.

5. Wu JT, Leung K, Leung GM. Nowcasting and forecasting the potential domestic and international spread of the 2019-nCoV outbreak originating in Wuhan, China: a modelling study. The Lancet. 2020;395(10225):689-97.

6. Clarke $\mathrm{S}$. The traffic data that shows the road into-and out ofCovid-19 lockdown. Guard. 2020. https://www.theguardian.com/ world/ng-interactive/2020/apr/27/the-traffic-data-thatshows-theroad-into-and-out-of-covid-19-lockdown

7. Molloy, J., Schatzmann, T., Schoeman, B., Tchervenkov, C., Hintermann, B., Axhausen, K. W., 2020. Observed impacts of COVID-19 on travel behavior in Switzerland based on a large GPS panel. Working paper. IVT, ETH Zurich.

8. Saladié O, Bustamante E, Gutiérrez A. COVID-19 lockdown and reduction of traffic accidents in Tarragona province, Spain. Transport Res Interdiscipl Perspect. 2020;8:100218.

9. World Health Organization (WHO), 2019. Global Status Report on Road Safety 2018. Geneva 2018.

10. Hsu Y-C, Shiu Y-M, Chou P-L, Chen Y-MJ. Vehicle insurance and the risk of road traffic accidents. Transport Res Part A Policy Pract. 2015;74:201-9.

11. Islam S, Islam R, Mannan F, Rahman S, Islam T. COVID-19 pandemic: an analysis of the healthcare, social and economic challenges in Bangladesh. Progress Disaster Sci. 2020;8:100135.

12. Bangladesh imposes total lockdown over COVID-19, Asia Pacific. https://www.aa.com.tr/en/asia-pacific/bangladesh-impos es-total-lockdown-over-covid-19/1778272. Accessed 29 May 2020.

13. Catchpole, J., Naznin, F., 2020. Impact of covid-19 on fatal crashes in Australia. Journal of Integrated Mobility. Issue 1 December 2020.

14. Coronavirus outbreak: shutdown won't be extended after May 30, The Daily Star. https://www.thedailystar.net/coronavirusoutbreak-shutdown-wont-be-extended-after-may-30-1905826. Accessed 29 May 2020.
15. "Coronavirus: Bangladesh declares public holiday from March 26 to April 4". Dhaka Tribune. https://www.dhakatribune.com/ bangladesh/2020/03/23/govt-offices-to-remain-closed-till-april-4. Accessed 24 Mar 2020

16. Sakamoto M, Begum S, Ahmed T. Vulnerabilities to COVID-19 in Bangladesh and a reconsideration of sustainable development Goals. Sustainability. 2020;2020(12):5296.

17. Institute of Epidemiology, Disease Control and Research (IEDCR). Bangladesh Covid-19 Update. https://covid19bd.idare. io/. Accessed 01 Apr 2021.

18. killed in road crashes in one month despite 'lockdown', UNB news. https://unb.com.bd/category/bangladesh/211-killed-in-roadcrashes-in-one-month-despite-lockdown/51017. Accessed 20 May 2020.

19. Coronavirus: 10 people killed each day in road accidents amid shutdown. Dhaka Tribune. https://www.dhakatribune.com/bangl adesh/2020/04/20/coronavirus-10-people-killed-each-day-in-roadaccidents-amid-shutdown. Accessed 22 Apr 2021.

20. people killed every day on average in road accidents in 2020 , Dhaka Tribune. https://www.dhakatribune.com/bangladesh/2021/ 01/09/report-18-people-killed-every-day-on-average-in-roadaccidents-in-2020. Accessed 20 Jan 2021.

21. Reducing Fatalities on Roads: Aim gets lowered. The Daily Star. https://www.thedailystar.net/backpage/news/fatalities-roads-roadsafety-authority-aims-lower-2046769. Accessed 20 Feb 2021.

22. COVID-19 Impact on the Road Transport Industry, IRU Library. https://www.iru.org/resources/iru-library/covid-19-impact-roadtransport-industry-update-november-2020. Accessed 20 Mar 2021.

23. Jenelius E, Cebecauer M. Impacts of COVID-19 on public transport ridership in Sweden: analysis of ticket validations, sales and passenger counts. Transp Res Interdis Perspect. 2020;8:100242.

24. Covid-19: Public transport services struggling for lack of passengers, Dhaka Tribune. https://www.dhakatribune.com/bangl adesh/2020/06/21/covid-19-public-transport-services-strugglingfor-lack-of-passengers. Accessed 20 July 2020.

25. Buses run staring at losses. The Financial Express. https://www. thefinancialexpress.com.bd/trade/buses-run-staring-at-losses1591500873. Accessed 08 June 2020.

26. Public transport to return as lockdown ends, with virus firmly entrenched. United News of Bangladesh (UNB). https://unb. com.bd/category/bangladesh/public-transport-to-return-as-lockd own-ends-with-virus-firmly-entrenched/52306. Accessed 31 May 2020.

27. Pandemic will change the aviation industry forever, The Daily Star. https://www.thedailystar.net/business/news/pandemic-willchange-the-aviation-industry-forever-1904584. Accessed 29 May 2020.

28 Anwar S, Nasrullah M, Hosen MJ. COVID-19 and Bangladesh: challenges and how to address them. Front Policy Brief Public Health. 2020. https://doi.org/10.3389/fpubh.2020.00154.

29. Army to run coronavirus quarantine units in Dhaka's Ashkona, Diabari. bdnews24.com. https://bdnews24.com/bangladesh/2020/ 03/20/army-to-run-coronavirus-quarantine-units-in-dhakas-ashko na-diabari. Accessed 20 Mar 2020.

30. Bangladesh to open small-scale train services after long shutdown. NEWAGE Bangladesh. https://www.newagebd.net/article/107262/ bangladesh-to-open-small-scale-train-services-after-long-shutd own. Accessed 30 May 2020.

31. Coronavirus: Bangladesh shuts train services. United News of Bangladesh (UNB). https://unb.com.bd/category/bangladesh/ coronavirus-bangladesh-shuts-train-services/47826. Accessed 30 Mar 2020.

32. Bangladesh shuts all train services. Dhaka Tribune. https://www. dhakatribune.com/bangladesh/2020/03/24/all-local-commu 
ter-mail-train-services-suspended-across-bangladesh. Accessed 25 Mar 2020.

33. Rail, launch operations restart Sunday, buses from Monday. Tribune. https://www.dhakatribune.com/bangladesh/dhaka/2020/05/ 29/rail-launch-operations-restart-tomorrow-buses-from-monday. Accessed 30 May 2020.

34. Bangladesh Railway plans to resume train services to avert loss. Dhaka Tribune. https://www.dhakatribune.com/bangladesh/2020/ 04/30/bangladesh-railway-to-resume-luggage-van-service-fromfriday. Accessed 30 April 2020.

35. Bangladesh Railway losing Tk 4-5cr every day. The Independent. https://www.theindependentbd.com/post/243880. Accessed 08 April 2020.

36. Road safety matters, more so during COVID-19. Published on End Poverty in South Asia. World Bank Blogs. https://blogs.world bank.org/endpovertyinsouthasia/road-safety-matters-more-so-during-covid-19. Accessed 20 Nov 2020.

37. Bangladesh sees record high daily coronavirus cases amid surge. Al Jazeera. https://www.aljazeera.com/news/2021/4/1/bangl adesh-witnesses-a-record-surge-in-coronavirus-cases. Accessed 02 April 2021.

38. Bangladesh extends coronavirus lockdown for another week. Al Jazeera. https://www.aljazeera.com/news/2021/4/19/bangl adesh-extends-coronavirus-lockdown-for-another-week. Accessed 20 April 2021.

39. Katrakazas C, Michelaraki E, Sekadakis M, Yannis G. A descriptive analysis of the effect of the COVID-19 pandemic on driving behavior and road safety. Transport Res Interdiscipl Perspect. 2020;7:100186.

40. Zafri NM, Khan A, Jamal S, Alam BM. Impacts of the COVID19 pandemic on active travel mode choice in Bangladesh: a study from the perspective of sustainability and new normal situation. Sustainability. 2021;13:6975.

41. Anwari N, Ahmed MT, Islam MR, Hadiuzzaman M, Amin S. Exploring the travel behavior changes caused by the COVID-19 crisis: a case study for a developing country. Transport Res Interdiscipl Perspect. 2021;9:1-16.

Publisher's Note Springer Nature remains neutral with regard to jurisdictional claims in published maps and institutional affiliations. 